\title{
Pericardial cyst: a benign anomaly
}

\author{
Krishnananda Nayak, ${ }^{1}$ Ranjan K Shetty, ${ }^{2}$ G Vivek, ${ }^{2}$ Umesh M Pai ${ }^{1}$ \\ ${ }^{1}$ Department of CVT, MCOAHS, Manipal, Karnataka, India \\ ${ }^{2}$ Department of Cardiology, Kasturba Medical College, Manipal, Karnataka, India
}

Correspondence to Dr G Vivek, vivekgraman@gmail.com

\section{DESCRIPTION}

A 54-year-old asymptomatic man was detected to have a prominent left heart border on a routine chest x-ray done during his annual health check (figure 1, arrows). Echocardiogram revealed a cystic lesion occupying the space antero-lateral to the right ventricular outflow tract (RVOT; figure 2). The cystic cavity did not produce any compression of the RVOT. CT of the chest showed a $6 \times 4 \mathrm{~cm}$ homogeneous smooth-walled cyst with no evidence of contrast enhancement or calcification (figures 3 and 4) confirming a pericardial cyst. Repeat echocardiogram done 6 months later did not show any progression of size.

Pericardial cysts are rare congenital anomaly located in the mediastinum. ${ }^{1}$ They are usually asymptomatic; but rarely produce symptoms based on their location and size. ${ }^{2}$ Commonly they are located in the right cardiophrenic angle, followed by the left, antero-superior and posterior mediastinum. ${ }^{3}$ They are usually unilocular, wellmarginated, spherical-shaped cysts lined with a single layer of mesothelial cells histologically. ${ }^{4}$ Most of the cysts are asymptomatic but occasional complications include obstruction of the RVOT, obstruction of the main bronchi and atelectesis, cardiac tamponade and sudden death. ${ }^{5}$ Imaging modalities include echocardiography, CT and

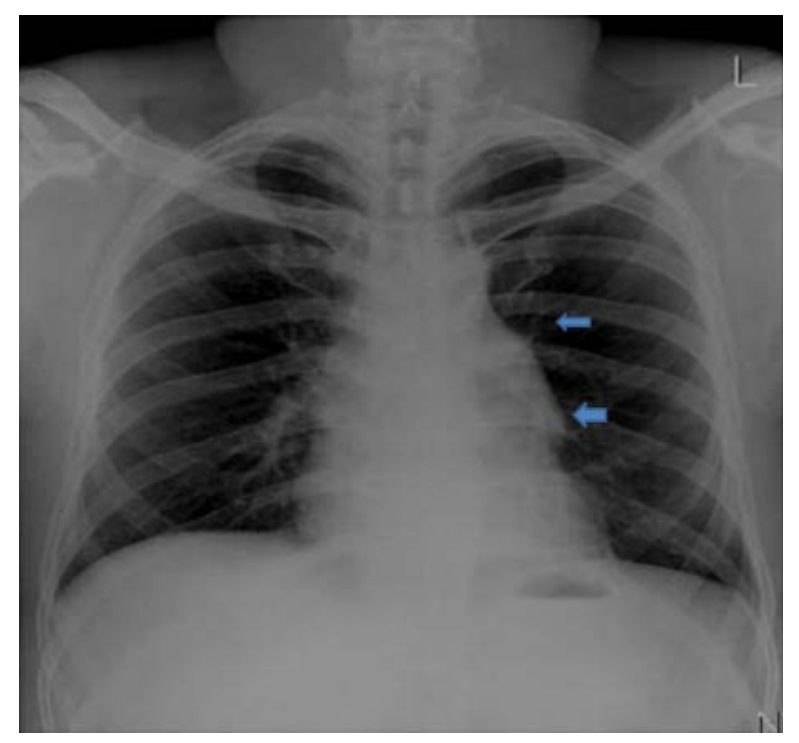

Figure 1 Chest $x$-ray showing prominence in the left heart border (arrows).

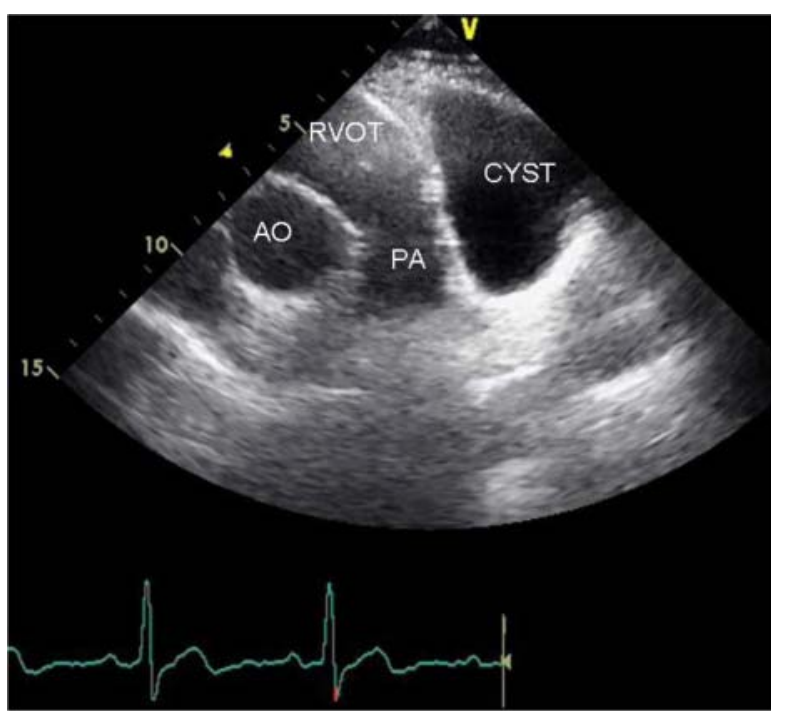

Figure 2 Echocardiograph (parasternal short axis view) showing a hypoechoic pericardial cyst which is to the left and anterior to the pulmonary artery. Ao, aorta; PA, pulmonary artery; RVOT, right ventricular outflow tract.

MRI. ${ }^{1}$ Usually close follow-up is sufficient in asymptomatic patients. Percutaneous drainage and surgical resection are the usual treatment modalities for symptomatic individuals.

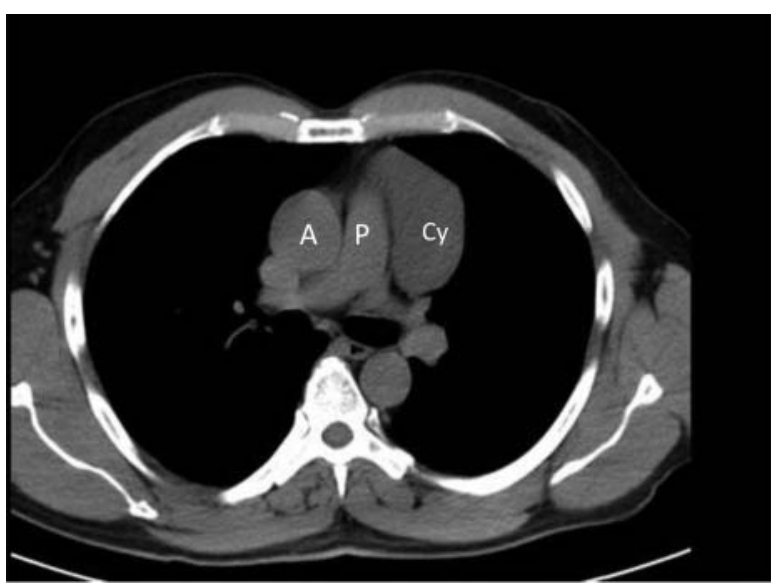

Figure 3 Contrast-enhanced CT of the chest, transverse view showing the cyst $(\mathrm{Cy})$ in relation to the pulmonary artery $(\mathrm{P})$ and aorta (A). 


\section{BMJ Case Reports}

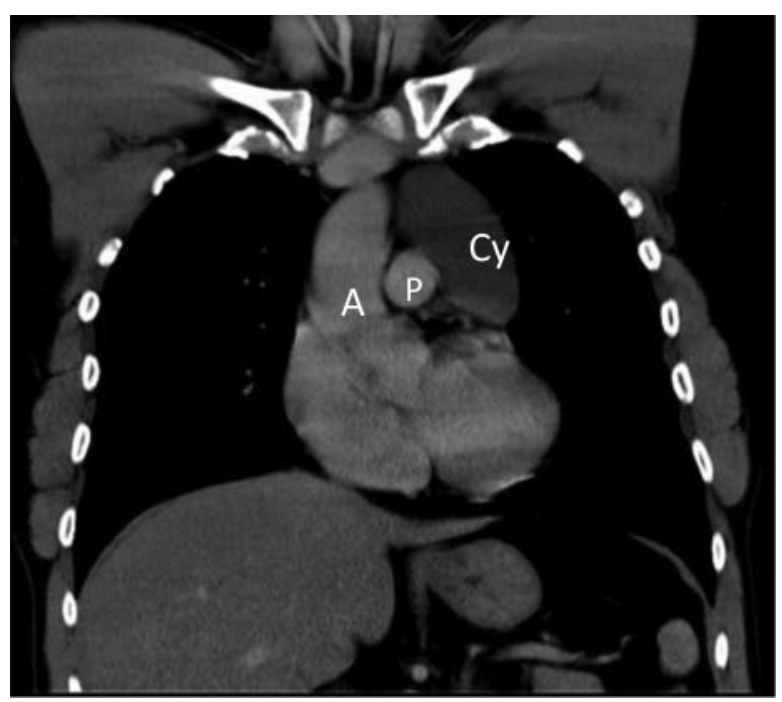

\section{Competing interests None.}

Patient consent Obtained.

\section{REFERENCES}

1. Patel J, Park C, Michaels J, et al. Pericardial cyst: case reports and a literature review. Echocardiography 2004;21:269-72.

2. Elamin WF, Hannan K. Pericardial cyst: an unusual cause of pneumonia. Cases J 2008;1:26.

3. Lau CL, Davis RD. Chapter 56: the mediastinum, in Sabiston's textbook of surgery. 17th edn. Philadelphia: Elsevier, 2004:1738-1739, 1758.

4. Strollo DC, Rosado-de-Christenson ML, Jett JR. Primary mediastinal tumors: part II. Tumors of the middle and posterior mediastinum. Chest 1997; 112:1344-57.

5. Fredman CS, Parsons SR, Aquino TI, et al. Sudden death after a stress test in a patient with a large pericardial cyst. Am Heart J 1994;127(4 Pt 1): 946-50.

Figure 4 Contrast-enhanced CT of the chest, coronal section showing the relationship of the cyst (Cy) to the pulmonary artery (P) and aorta (A).

Learning points

- Pericardial cysts are rare benign mediastinal masses usually detected in asymptomatic individuals.

- Rare complications include compression of the bronchi, ventricular outflow tract, rupture with tamponade and sudden death.

- Treatment in symptomatic individuals includes surgical resection or percutaneous aspiration.

This pdf has been created automatically from the final edited text and images.

Copyright 2012 BMJ Publishing Group. All rights reserved. For permission to reuse any of this content visit http://group.bmj.com/group/rights-licensing/permissions.

BMJ Case Report Fellows may re-use this article for personal use and teaching without any further permission.

Please cite this article as follows (you will need to access the article online to obtain the date of publication).

Nayak K, Shetty RK, Vivek G, Pai UM. Pericardial cyst: a benign anomaly. BMJ Case Reports 2012;10.1136/bcr-03-2012-5984, Published XXX

Become a Fellow of BMJ Case Reports today and you can:

- Submit as many cases as you like

- Enjoy fast sympathetic peer review and rapid publication of accepted articles

- Access all the published articles

- Re-use any of the published material for personal use and teaching without further permission

For information on Institutional Fellowships contact consortiasales@bmigroup.com

Visit casereports.bmj.com for more articles like this and to become a Fellow 